\title{
Resourcing the Internal Audit Function: How Effective is the Audit Committee?
}

\author{
$\mathrm{Ng}$ Shir Li (Corresponding Author) \\ Lecturer, Department of Accounting, Sunway University Business School \\ 47500 Subang Jaya, Selangor, Malaysia \\ E-mail: shirlin@sunway.edu.my
}

\author{
Dennis W Taylor \\ Professor, School of Accounting, RMIT University \\ 3000 Melbourne, Victoria, Australia \\ E-mail: dennis.taylor@rmit.edu.au
}

Received: July 3, 2017 Accepted: Oct. 30, $2017 \quad$ Published: December 1, 2017

doi:10.5296/ajfa.v9i2.11937 URL: https://doi.org/10.5296/ajfa.v9i2.11937

\begin{abstract}
The aim of this study is to investigate the extent to which an Audit Committee (AC)'s own governance characteristics impact on its role effectiveness in achieving enhanced resourcing and by extension, improved the scope and quality of the Internal Audit Function (IAF). Sample is drawn from top 300 companies listed on the Australian Stock Exchange (ASX). This study combines data from a questionnaire administered to the Internal Audit Executive (IAE) with information from annual reports and financial databases. Hypotheses are developed and tested using multiple regression analysis. This analysis is supplemented by insights from a comparative case study for two companies in the sample. Results reveal that AC size is significantly positively related to the financial resources (budget) allocated to IAF, while both AC financial expertise and AC size are significantly positively related to IAF labour hours. Results also confirm that IAF's with higher resourcing are able to concentrate those resources on areas expected of a high quality IAF. Further, comparative case study analysis gives insights to the superior ways a larger size AC can be effective in fulfilling its oversight role, building its working relationships and obtaining resources for the IAF. Study
\end{abstract}


contributes to current auditing-related governance literature by introducing a comprehensive empirical model of AC effectiveness in facilitating the scope and quality of the IAF's work. Also, the findings have implications for regulators and the Institute of Internal Auditors (IIA) in terms of the composition and functioning of ACs.

Keywords: Audit committee, internal audit function, corporate governance, audit committee effectiveness, audit committee characteristics 


\section{Introduction}

The role of audit committees (ACs) has broadened since the corporate governance reforms of the mid-2000s and the subsequent risk excesses exposed by the global financial crisis. Prior to the mid-2000s, the focus of ACs was predominantly on vetting the company's financial reporting compliance and overseeing the external auditors. Since then, the role of ACs has extended into a more comprehensive oversight of internal control and risk management systems. An AC is now expected to play a key role in assisting the board to fulfil its corporate governance and oversight responsibilities in relation to risk management, control, and governance processes (Aldamen et al, 2012). This direction of role expansion of ACs brings their work more fully into the field of the Internal Audit Function (IAF). The IAF is clearly central to the AC's expanded role because, according to Institute of Internal Auditors (2004), the responsibility of internal auditing is to evaluate and provide reasonable assurance such that risk management, controls, and governance systems are functioning as intended. While existing corporate governance regulations do not address the interaction between the AC and the IAF, the tradition in most companies has been that the Internal Audit Executive (IAE) reports to either the Chief Financial Officer (CFO) or the Chief Risk Officer (CRO) (Deloitte, 2013). However, today the IAE usually reports directly to the $\mathrm{AC}$, or the $\mathrm{AC}$ will have a role in hiring, firing, evaluating and compensating the IAE (Deloitte, 2015). The AC's increasing role with regard to internal auditing is being undertaken to help ensure the IAE's independence and adequate resourcing of the IAF (IIA Research Foundation, 2003).

Previous studies in Australia on relationships between the AC and the IAF (Cooper, 1993; Goodwin, 2003; Goodwin \& Kent, 2006; Singh \& Newby, 2010) have been conducted on data from the years before the refinement of corporate governance guidelines, especially before the implementation of the Australian Stock Exchange Corporate Governance Council (ASX CGC) revised 2007 edition. Thus, this study seeks to update the evidence in the research literature on the effectiveness of ACs in fulfilling their expanded role in the area of the IAF. Moreover, previous studies on the interface between the AC and the IAF have mainly been from the perspective of the IAF. For example, Gwilliam and Kilcommins (1998) investigate how the independence of the IAF is enhanced by support from the AC, Scarbrough et al (1998) address the issue of IAE having good communications with the AC, and Goodwin (2003) investigates how the IAF facilitates the responsibilities of the AC. Therefore, there is a dearth of research that has examined the relationship between the IAF and the AC from the viewpoint of the AC.

Complexity in the relationship between the $\mathrm{AC}$ and the IAF stems from the multiple demands on their roles. Both the AC and the IAF are expected to perform a monitoring role and also an advisory role. The AC monitors the IAF (and other functions) and advises the board, whereas the IAF monitors the company's systems and processes and advises management and the AC. Overlaying these roles in the corporate governance fabric are the key issue of independence. In corporate governance, independence is important in three fundamental contexts. These are that external auditors are independent of their clients; that internal auditors are independent of the colleagues they are auditing; and that non-executive directors have a degree of independence from their executive colleagues on a board. The independence of the AC and 
the IAF respectively can be conflicted by their need to simultaneously play a monitoring and advisory role. Strong resourcing of the IAF, both in the IAF's budget allocation and labour hours would be a prerequisite for enhancing the scope and quality of the IAF's monitoring and advisory activities. The extent of influence of the AC over management in the resourcing of the IAF would also be a factor in maintenance the IAF's independence from management. This AC role of overseeing the resourcing of the IAF could be carried out through the AC exercising either greater advocacy or greater authority in obtaining improved company budget allocation for the IAF and higher labour hours devoted to the IAF.

In this study, the focus is on the AC's effectiveness in fulfilling its critical modern-day role of overseeing and supporting the resourcing of the IAF. The concept of AC effectiveness has been benchmarked in prior corporate governance studies against the AC's own structure and members' governance characteristics. These good governance characteristics of the AC and its members include independence, financial and industry expertise, frequency of meetings, size of the committee, and the existence of an AC charter (Kalbers \& Fogarty, 1993; Goodwin \& Yeo, 2001; DeZoort et al, 2002; Carcello et al, 2002; Abbott et al, 2003; Carcello et al, 2005; Lary \& Taylor, 2012). The inference is that the effectiveness of an AC in fulfilling its combined monitoring, advisory and independence roles will be reflected in the strength of its own good governance characteristics. As argued by DeZoort and Salterio (2001), the effectiveness of an AC is likely to be embodied in its members' collective characteristics of being competent, inquisitive and decisive.

Thus, this leads to the primary objective of this study:

To investigate the extent to which an AC's own governance characteristics impact on its role effectiveness in achieving enhanced resourcing for the IAF.

The reminder of this paper is structured as follows. Section 2 provides a discussion on the literature review. This is followed by formulation of hypothesis of this study. Section 4 describes the research method used, with section 5 providing data analysis and discussion. Further, section 6 provides a comparative case study analysis for two companies in the sample. Section 7 concludes by summarizing the findings and discussing the implications of the results and future opportunities for this study.

\section{Literature Review}

\subsection{Audit committee and internal audit function}

Previous studies have concluded that an effective AC can heighten the status of the IAF and at the same time, the IAF can help the AC in its oversight role (Cooper, 1993; Scarbrough et al, 1998; Raghunandan et al, 1998; Raghunandan et al, 2001; Goodwin, 2003; Abbott et al, 2003; Carcello et al, 2005; Abbott et al, 2010). In addressing the relationship between the AC and the IAF, studies such as Scarbrough et al (1998) and Raghunandan et al (2001) examine the association between $\mathrm{AC}$ composition and the committee's interaction with internal auditing. Both studies use the same method by surveying a sample of IAEs in publicly held manufacturing companies. Scarbrough et al (1998)'s study is performed in Canada using a larger sample size while Raghunandan et al (2001)'s United States study uses a smaller 
sample. Both consistently find that ACs consisting of solely non-employee directors are more likely to have frequent meetings with the IAE and review the internal auditing program.

Goodwin (2003) performs a similar study in Australia and New Zealand in which the separate influences of independence and financial expertise on AC relations with the IAF are investigated. Goodwin (2003) finds independence and accounting experience have a complementary impact on AC relations with internal auditing. In a similar vein, Raghunandan et al. (1998) analyses the perceived level of knowledge of ACs. They find that ACs granted private access to the IAEs and reviewed both the plans and results of internal auditing are more likely to be perceived as knowledgeable. It is likely that ACs having closer communication with the IAF and have better knowledge of the IAF activities will be more willing/able to achieve stronger resourcing for the IAF in the expectation of attaining high quality for the IAF. Another perspective on the effect of the AC on resourcing of the IAF is given by Abbott et al (2010). Based on a survey of 134 IAEs from Fortune 1000 companies, they find that ACs with greater IAF oversight are associated with a larger percentage of IAF hours being worked. Their result infers that ACs demanding strong internal controls, risk management and good governance compliance will tend to cause higher IAF effort (reflected in hours) on these areas of responsibility.

\subsection{Audit committee effectiveness}

The subjectivity of the notion of AC effectiveness and its multi-facetted nature means that a more indirect measure of $\mathrm{AC}$ effectiveness based on objective and publicly available data have been taken. Previous literature has adopted different proxies to determine the effectiveness of ACs in their monitoring roles.

DeZoort et al (2002) characterize the effectiveness of AC as having qualified members with the authority and resources to protect stakeholders' interests by ensuring reliable financial reporting, internal controls, and risk management through its diligent oversight efforts. Similarly, Kalbers and Fogarty (1993) define AC effectiveness as the competency of AC to undertake specified oversight responsibilities in the company. Specific focus has also been given to AC effectiveness in overseeing and supporting the IAF. Carcello et al (2005) conceive AC effectiveness as an ability to oversee the IAF's activities which are measured by total internal audit budget. Alternatively, Goodwin and Yeo (2001) assess the effectiveness of $\mathrm{AC}$ as an ability to maintain IAF independence whether in appearance or fact. As suggested by Lary and Taylor (2012), the effectiveness of Australian ACs can be benchmarked against their many roles and responsibilities.

Thus, drawing upon the recommendations in the Australian ASX Corporate Governance Council (2007), it can be argued that for an AC to be effective, it must exhibit at least five characteristics. These five characteristics which are explained in turn below, can act as a suitable construct in testing the effect of AC effectiveness on the resourcing of the IAF in this study.

\subsubsection{Audit committee independence}

The independence of $\mathrm{AC}$ chair and members is deemed to be an important characteristic 
enabling AC effectiveness. Fama and Jensen (1983) argue that independent AC members as outside directors may view the directorate as a means of enhancing their reputations as experts in monitoring and achieving quality from agents they monitor. According to ASX Corporate Governance Council (2007) Recommendation 4.2, the AC should be structured so that it comprises only of non-executive directors, consists of a majority of independent directors and is chaired by an independent chair who is not the chair of the board. This recommendation is justified by the findings of previous studies which establish that $\mathrm{AC}$ independence is associated with the committee's performance of its roles (Abbott et al, 2000; Beasley et al, 2000; Carcello \& Neal, 2000; Goodwin \& Yeo, 2001; Klein, 2002; Abbott et al, 2004).

\subsubsection{Audit committee expertise}

AC expertise is considered another key characteristic for the AC to effectively fulfil its roles. ASX Corporate Governance Council (2007) Recommendation 4.3 states that an AC should include members who are all financially competent, at least one member should have relevant accounting or financial qualifications and also some members should have an understanding of the industry in which the entity operates. This would not only enable the AC to vet the financial statements, but also to understand and evaluate the financial resources needs of the IAF for achieving its scope and quality of work (Munro \& Buckby, 2008). Findings from earlier studies have shown that financial expertise is essential for AC members to perform their role well (Raghunandan et al, 2001; DeZoort \& Salterio, 2001; Abbott et al, 2003; Goodwin, 2003; Xie et al, 2003; Abbott et al, 2004; Davidson et al, 2004).

\subsubsection{Audit committee frequency of meetings}

ASX Corporate Governance Council does not provide recommendations on the number of meetings that an AC should have each year. The number of AC meetings held each year may differ and should depend on the size and the risk of the business. Evidence supports the significance of AC frequency of meetings (Beasley et al, 2000; Xie et al, 2003; Abbott et al, 2004). Beasley et al (2000) find that more frequent AC meetings is associated with less fraud. This and other results infer that ACs that meet more frequently are more likely to be up to date about, and attentive to the company's current auditing issues and auditing resourcing needs.

\subsubsection{Audit committee size}

AC size of membership is also important to the overall strength of the AC. Felo et al (2003) posit that a larger AC increases financial reporting quality because it is more likely to discover and solve potential risks in the financial reporting process. Furthermore, Lin et al (2006) find that companies with ACs comprising of at least four members are less likely to experience earnings restatements. Dalton et al (1998) also find a positive association between $\mathrm{AC}$ size and the monitoring function of the board. Based on these results, a larger $\mathrm{AC}$ is necessary for effective monitoring of the IAF and its resourcing needs. Although ASX Corporate Governance Council (2007) Recommendation 4.2 states that an AC should have at least three members, companies may choose to have more than three members. This study 
uses the same argument that a larger size AC would have more diverse skills and knowledge to enhance its monitoring and advisory roles and potentially, its advocacy role in respect of the IAF's resourcing determination.

\subsubsection{Audit committee charter}

An AC charter can provide effectiveness to the AC because it gives formality, and hence authority to the scope of the AC's roles, responsibilities, powers and rights. According to ASX Corporate Governance Council (2007) Recommendation 4.3, an AC should have a formal charter. Kalbers and Fogarty (1993) argue that the existence of a clear AC charter provides power for authoritative decision-making and enables the AC to achieve its oversight role more effectively.

\section{Hypothesis formulation}

As discussed, the responsibilities of the IAF have broadened and the oversight role of ACs has expanded more fully into the field of the IAF in recent years. This field of the IAF covers responsibilities for evaluating and providing reasonable assurance so that risk management, internal control, and governance systems are functioning as intended. Hence, an effective AC with a strong working relationship with the IAF can be helpful to the IAF in performing its responsibilities (Scarbrough et al, 1998; Institute of Internal Auditors, 2002a; Institute of Internal Auditors, 2002b; Institute of Internal Auditors, 2003b). This study's primary aim is to investigate whether the effectiveness of an $\mathrm{AC}$, benchmarked on its own governance characteristics is associated with the resourcing level of the IAF, both in funding and labour hours devoted to the IAF. It is argued that a more independent, diligent, expert and powerful $\mathrm{AC}$ will be more effective in communicating with and understanding the scope and quality of the IAF's work and its resourcing needs.

Hence, an AC with an independent chair, more frequent meetings, a higher proportion of financially qualified and industry experienced members, a larger size of membership and a strong charter, will be more cognizant of and capable of advocating for the resourcing needs required by the IAF to fulfil its complex scope of responsibilities at a high level of quality.

The following hypothesis is formulated:

The AC's mechanisms for role effectiveness based on its governance characteristics are positively related to (a) financial resources (budget) and (b) labour resources (hours) devoted to the IAF.

\section{Research methods}

\subsection{Sample}

The sampling frame for this study is top 300 companies listed on the ASX for the financial year ending in 30 June 2010. A total of 255 companies are drawn from the sampling frame on an elimination basis. Company data for the financial year ending in 30 June 2010 is selected because the ASX listing rules require top 300 listed companies to have an audit committee and comply with the recommendations of the ASX Corporate Governance Council's 
Principles and Recommendations on the composition, operation and responsibility of an AC (Auditing \& Assurance Standards Board, Australian Institute of Company Directors, \& Institute of Internal Auditors Australia, 2008).

\subsection{Questionnaire}

A questionnaire is developed and administered to IAEs of the sampled companies. This method is considered appropriate because IAE is likely to be knowledgeable about the company's IAF and the operations of the AC (Goodwin \& Yeo, 2001). The information sought from IAE in the questionnaire is divided into four sections. Section one relates to background of both the IAE and the company. Section two asks respondents about the IAF activities while section three seeks data on the relationship between the AC and the IAF. The fourth section asks respondents about the independence of the IAF. The questionnaire is pre-tested on four academics with familiarity in auditing and corporate governance research experience. It is also presented to the manager of research and publishing at the Institute of Internal Auditors (IIA) Australia for review and approval before its distribution to IIA members for pilot testing.

\subsection{Data collection}

There are two stages of data collection employed in this study. In the first stage, primary data is collected by mailing a questionnaire to IAEs of sampled companies. The pilot test of the questionnaire is electronically sent by IIA Australia to a limited number of their members who are IAEs in the top 300 ASX listed companies. A total of 9 usable responses are received, yielding a response rate of only $15 \%$. Due to poor response rate, the questionnaire is administered directly to the IAEs of top 300 ASX listed companies. A total of 36 respondents are received, representing a response rate of 14\%. Compared to other studies' response rates (Carcello et al, 2005 (25\%); Christopher et al, 2009 (17\%); Abbott et al, 2010 (13\%)), the response rate for this study is deemed fairly reasonable and may present a fair reflection of the view of the IAEs. In the second stage of data collection, secondary data (i.e., financial, market data and text in the annual reports) is obtained from online databases.

\subsection{Variables and measurements}

The independent variables for this study are proxy measures of $\mathrm{AC}$ governance characteristics. First, AC chair independence (ACCHAIRIND) is measured as a scale where scores are assigned to AC Chair, Chief Executive Officer (CEO) and Chief Financial Officer (CFO) based on respective qualification and industry experience categories as shown in Table 1 . The numbers assigned to categories in Table 1 are for purposes of determining the extent of matching/non-matching of the background of $\mathrm{AC}$ chair with the backgrounds of the $\mathrm{CEO}$ and the CFO. 
Table 1. Qualification, industry and category

\begin{tabular}{|l|c|}
\hline Qualification & Category \\
\hline Accounting and finance & 1 \\
\hline Engineering & 2 \\
\hline Law and arts & 3 \\
\hline Health and science & 4 \\
\hline Management and marketing & 5 \\
\hline
\end{tabular}

\begin{tabular}{|l|c|}
\hline Industry & Category \\
\hline Mining and energy & 1 \\
\hline Banking, insurance, finance and law & 2 \\
\hline Service and retail & 3 \\
\hline Manufacturing & 4 \\
\hline Health & 5 \\
\hline
\end{tabular}

Because there can be multiple qualifications and industry experiences in the background of any individual, the numbering scheme needs to ensure uniqueness of multiple backgrounds. This is achieved by adding a 0 to the category number if a single background category applies to an individual, and combining the digits if a multiple background applies. For example, if an $\mathrm{AC}$ chair has an accounting qualification, a score of 10 would be given as 1 for accounting and finance qualification category and 0 for no second qualification. Scores for AC chair qualification, $\mathrm{AC}$ chair industry experience, $\mathrm{CEO}$ qualification, $\mathrm{CEO}$ industry experience, CFO qualification and CFO industry experience are each collected. Subsequently, a new single numbered score is assigned if chair of AC matches or does not match one or more of the requirements: same qualifications to CEO and CFO and same industry experience to CEO and CFO. In the end, the scores will be totaled up. Thus, the scale can range from 0 (i.e., chair of AC is very independent) to 4 (i.e., chair of AC is not independent) as shown in Table 2. It can be argued that with different qualifications and industry experience between the chair of the AC, CEO and CFO, the chair of the AC can be viewed as independent from the management because he/she would have a different mindset and arguments relating to particular financial reporting and internal auditing issues in the company and it is not dominated by one individual. 
Table 2. Overview or total scores

\begin{tabular}{|l|c|c|}
\hline \multicolumn{3}{|c|}{ AC Chair Independence } \\
\hline & Qualification & Industry experience \\
\hline Chief executive officer (CEO) & $1 / 0$ & $1 / 0$ \\
\hline Chief financial officer (CFO) & $1 / 0$ & $1 / 0$ \\
\hline Total & $\begin{array}{c}4 / 0 \text { is the maximum/minimum score for AC chair } \\
\text { independence from both the CEO and CFO }\end{array}$ \\
\hline
\end{tabular}

Second, AC expertise is measured by two independent variables: accounting/financial expertise (ACEXP) and industry expertise (ACINDUS). ACEXP is a ratio of number of AC members with accounting or financial qualification to total number of $\mathrm{AC}$ members while ACINDUS is a ratio of number of AC members who has worked in the same industry as the company for a substantial number of years (at least 10 years) to total number of $\mathrm{AC}$ members. Third, AC frequency of meetings (ACMEET) is measured as the number of AC meetings held during the financial year. Fourth, AC size (ACSIZE) is measured as the number of members serving on the AC during the financial year (Goodwin \& Kent, 2006; Yatim et al, 2006; Hoitash \& Hoitash, 2008; Singh \& Newby, 2010). Lastly, AC charter (ACCHAR) is measured as a categorical variable, equal to the value of " 1 " if the $\mathrm{AC}$ has a charter and " 0 " otherwise.

There are two dependent variables employed in this study. First, the IAF's budget (IAFBUD) is measured as total annual IAF budget multiplied by full-time equivalent staff. Total IAF budget is presented in categories and self-selected by the respondent in the questionnaire. Second, the IAF labour hours (IAHOUR) is measured as full-time equivalent staff working in the IAF. Full-time equivalent staff is a unit that indicates the workload of a full-time employee employed in the IAF in a way that makes workload comparable across the companies collected in the sample of this study. To obtain a measure of full-time equivalent staff, the numerator of the formula is a multiplication of two products: maximum weekly working hours multiply by working weeks per year. The standard maximum weekly working hours in Australia is 38 weeks and the average working weeks per year is 52 weeks. The denominator of the formula is total hours per employee that are devoted to internal audit services which are obtained from the questionnaire. Then, the whole fraction is multiply by the number of internal audit staff employed in the company which is also obtained from the questionnaire. A mathematical representation of full-time equivalent staff is shown in Table 3. 
Table 3. Mathematical representation of full-time equivalent staff

Maximum weekly working hours $\times$ Working weeks per year

Total hours per employee that are devoted to internal audit services
Number of internal audit staff employed in the company

Control variables that may affect the hypothesized relationship in this study are considered. This study controls for firm size: natural log of total assets (LNTA). It also includes the ratio of total long-term debt to total assets (LEVERAGE). Positive associations between these control variables and IAF resources (dependent variables) would be expected. Since firm complexity has the potential to increase the need for assurance of internal controls and risk management, this study expects the control variables such as ratio of inventory to total assets (INVENRATIO), ratio of receivables to total assets (RECRATIO), ratio of number of foreign subsidiaries to total number of subsidiaries (FORSUB) and square root of total number of subsidiaries (SUB) to be positively related to the dependent variables. This study also controls for firm growth (Carcello et al, 2005; Abbott et al, 2010) where there will be a positive relationship between the three-year rate of sales growth (GROWTH) and the dependent variables. Furthermore, similar to Carcello et al (2005), this study also expects a positive sign for operating cash flow (OPCASH) and ratio of current assets to current liabilities (CURATIO).

\subsection{Research design}

The two regression models used to test the two part of the hypothesis are:

Model 1

IAFBUD $=\mathrm{b} 0+\mathrm{b} 1$ ACCHAIRIND $+\mathrm{b} 2$ ACEXP + b3ACINDUS + b4ACMEET + b5ACSIZE + b6ACCHAR + b7BIG4 + b8LNTA + b9LEVERAGE + b10RECRATIO + b11INVENRATIO + b12CURATIO + b13OPCASH + b14FORSUB + b15SUB + b16LNAUDFEES + b17GROWTH $+\varepsilon$

Model 2

IAHOUR $=\mathrm{b} 0+\mathrm{b} 1 \mathrm{ACCHAIRIND}+\mathrm{b} 2 \mathrm{ACEXP}+\mathrm{b} 3$ ACINDUS $+\mathrm{b}$ 4ACMEET + b5ACSIZE + b6ACCHAR + b7BIG4 + b8LNTA + b9LEVERAGE + b10RECRATIO + b11INVENRATIO + b12CURATIO + b13OPCASH + b14FORSUB + b15SUB + b16LNAUDFEES + b17GROWTH $+\varepsilon$

Where:

IAFBUD is the total annual internal audit budget measure $\mathrm{x}$ full- time equivalent staff.

IAHOUR is the full- time equivalent staff working in the IAF.

ACCHAIRIND is the ratio of total scores assigned to AC chair independence.

ACEXP is the ratio of number of AC members with accounting or financial qualifications to total AC members. 
ACINDUS is the ratio of number of AC members worked in the same industry for a substantial number of years (at least 10 years) to total AC members.

ACMEET is the number of AC meetings held during the financial year.

ACSIZE is the number of members serving on the AC during the financial year.

ACCHAR is equal to the value of " 1 " if AC has a charter and " 0 " otherwise.

BIG4 is equal to the value of " 1 " if a Big 4 auditor is used and " 0 " when a smaller audit firm is used.

LNTA is the natural log of total assets.

LEVERAGE is the ratio of total long-term debt to total assets.

RECRATIO is the ratio of receivables to total assets.

INVENRATIO is the ratio of inventory to total assets.

CURATIO is the ratio of current assets to current liabilities.

OPCASH is the ratio of operating cash flow to total assets.

FORSUB is the ratio of number of foreign subsidiaries to total number of subsidiaries.

SUB is the square root of total number of subsidiaries.

LNAUDFEES is the natural log of total audit fees paid to external auditor.

GROWTH is the three-year rate of sales growth.

$\varepsilon$ is the error term of the ordinary least squares regression.

\section{Results and discussion}

\subsection{Descriptive statistics}

The descriptive statistics for variables in the regression models are presented in Tables 4 and 5. Table 4 gives results relating to the IAF's resources. In Panel A, it shows $58 \%$ of the respondents' IAF have less than 5 professional internal audit staff employed and only $8 \%$ have more than 20 professional internal audit staff employed. Panel A further shows the extent of money resources in the form of the total annual IAF budget. More than half, $54 \%$ of the respondents' IAF has a total annual budget ranging from $\$ 201000$ to $\$ 1000000$, with a further $31 \%$ reporting a total annual budget, above $\$ 1000000$. Turning to the work activity level of the IAF, Panel B in Table 4 indicates the total hours devoted to internal audit services. On average, 1489 hours per annum (or 29 hours per week) per person are devoted to internal audit services by professional staff during the 2010 financial year. This suggests not all professional staff is employed in the IAF on a full-time basis. 
Table 4. Internal audit function activities

\section{PANEL A}

No. Questionnaire items

\section{Frequency}

No \%

8. How many professional internal audit staff is employed in your company?

Less than 5

Between 5-10

$21 \quad 58$

Between 11-15

925

Between 16-20

26

More than 20

13

38

9. What is the total annual internal audit budget?
$\$ 20000$ and below
$\$ 21000$ to $\$ 50000$
13
$\$ 51000$ to $\$ 100000$
13
$\$ 101000$ to $\$ 200000$
13
$\$ 201000$ to $\$ 500000$
26
$\$ 501000$ to $\$ 1000000$
$10 \quad 27$
$\$ 1001000$ and above

$10 \quad 27$

$11 \quad 31$

\section{PANEL B}

\begin{tabular}{llccccc}
\hline No. & Questionnaire items & Mean & Median & $\mathbf{2 5}^{\text {th }} \%$ & $\mathbf{7 5}^{\text {th }} \%$ & Std. Dev. \\
\hline 10. & $\begin{array}{l}\text { How many total hours are } \\
\text { devoted to internal audit } \\
\text { services by professional }\end{array}$ & 1488.89 & 1550.00 & 1060.00 & 1975.00 & 661.13 \\
& $\begin{array}{l}\text { staff (per person) during } \\
\text { your company's most } \\
\text { recent financial year? }\end{array}$ & & & & & \\
\hline
\end{tabular}

Descriptive statistics for the variables in Table 5 are drawn from published data of the 36 respondents' companies. Panel A of Table 5 shows that size of ACs (ACSIZE) ranges from 2 to 9 members, with a mean of 3.53 members. On average, $4.47 \mathrm{AC}$ frequency of meetings (ACMEET) are held during the 2010 financial year with a minimum of 0 meeting and a maximum of 9 meetings. The mean percentage of AC members with accounting or financial qualifications to total members (ACEXP) is $69 \%$, ranging from $25 \%$ to $100 \%$. Furthermore, the mean percentage of total AC members that have worked in the same industry for at least 10 years (ACINDUS) is about 50\%. Further, the mean AC chair independence (ACCHAIRIND) is $65 \%$ of cases. The inference from these results is that AC characteristics of size and frequency of meetings, expertise and independence are quite variable across the 36 companies. The total audit fees paid to the external auditors (AUDFEES) range from a minimum of $\$ 0.13$ million to a maximum of $\$ 16.38$ million, with a mean of $\$ 2.74$ million.

In regression Models 1 and 2, the dependent variables are measures of the IAF's relative extent of monetary resourcing (IAFBUD) and human resourcing (IAFHOUR). They reflect 
the importance accorded to the IAF, which should largely be championed by the AC as the company's oversight body for the IAF. Table 5, Panel A, shows that the average total annual internal audit budget per full-time equivalent internal audit staff member (IAFBUD) is $\$ 45.56$, ranging from a minimum of $\$ 0$ to a maximum of $\$ 532$. The number of full-time equivalent staff working in the IAF (IAHOUR) is between 0 and 76 with an average staff size of 6.83. Additional corporate governance characteristics are shown in Panel B of Table 5. Results indicate that almost all companies in the sample have a formal charter for their AC. Also almost all companies engage a Big 4 auditor firm as their external auditors.

Table 5. Descriptive statistics for Model 1 and Model 2

\begin{tabular}{|c|c|c|c|c|c|}
\hline \multicolumn{6}{|c|}{ PANEL A: Continuous Variables } \\
\hline Variable Name & Mean & Median & Minimum & Maximum & $\begin{array}{l}\text { Standard } \\
\text { Deviation }\end{array}$ \\
\hline ACCHAIRIND & 0.65 & 0.75 & 0.25 & 1.00 & 0.24 \\
\hline ACEXP & 0.69 & 0.67 & 0.25 & 1.00 & 0.21 \\
\hline ACINDUS & 0.50 & 0.33 & 0.00 & 1.00 & 0.28 \\
\hline ACMEET & 4.47 & 4.00 & 0.00 & 9.00 & 1.86 \\
\hline ACSIZE & 3.53 & 3.00 & 2.00 & 9.00 & 1.16 \\
\hline IAFBUD & 45.56 & 13.00 & 0.00 & 532.00 & 96.20 \\
\hline IAHOUR & 6.83 & 2.00 & 0.00 & 76.00 & 13.67 \\
\hline AUDFEES (\$) & $2.74 \mathrm{M}$ & $1.14 \mathrm{M}$ & $0.13 \mathrm{M}$ & $16.38 \mathrm{M}$ & $4.11 \mathrm{M}$ \\
\hline \multicolumn{6}{|c|}{ PANEL B: Dichotomous Variables } \\
\hline Variable Name & Mean & Median & $\begin{array}{c}\text { Number of } \\
\text { Firms Coded "0" }\end{array}$ & \multicolumn{2}{|c|}{$\begin{array}{l}\text { Number of Firms } \\
\text { Coded "1" }\end{array}$} \\
\hline ACCHAR & 0.94 & 1.00 & 2 & \multicolumn{2}{|c|}{34} \\
\hline BIG4 & 0.97 & 1.00 & 1 & \multicolumn{2}{|c|}{35} \\
\hline
\end{tabular}

\subsection{Hypothesis testing}

\subsubsection{Normality of the variables}

Initial descriptive statistics for the variables to be modeled in this study suggest that all the independent variables have non-normality in their data distributions. Non-normality is detected for these variables due to significance values for both Kolmogorov-Smirnov test and Shapiro-Walk test $(\mathrm{p}<0.05)$. Also, skewness and kurtosis levels are found to be outside normal tolerance limits. For all the independent variables in both the models employed to test the hypothesis of the study, Blom normal score transformation is applied because neither logarithmic nor square root transformation is able to yield a normal distribution of these measures (Kanel et al, 2008). 


\subsubsection{Test for small sample size}

To gauge whether the sample size in this study has a direct and sizable impact on statistical power, Hair et al (1995)'s criterion is used. This criterion compares the significance level $(\alpha)$ and the number of independent variables in detecting a significant $\mathrm{R}^{2}$. The values provided are the minimum $\mathrm{R}^{2}$ that the given sample size will detect as statistically significant at significance level $(\alpha)$ of 0.05 . This study employs 6 independent variables and 11 control variables. With sample size of $36(>20)$, these results satisfy the sample size statistical power test as regression models have $\mathrm{R}^{2}$ more than $70 \%$. According to Hair et al (1995) the minimum $\mathrm{R}^{2}$ that a specified sample size will detect as statistically significant at the 0.05 significance level is $42 \%$.

\subsubsection{Choice of stepwise regression}

In stepwise multiple regression, the independent variables are entered according to their statistical contribution in explaining the variance in the dependent variable. Stepwise regression is used in this study because it reduces the number of independent variables in the model by excluding non-significant variables. This study has 6 independent variables and 11 control variables. Therefore, stepwise regression is considered the suitable choice of analysis by finding the set of predictors that are most effective in predicting the dependent variable.

\subsubsection{Regression analysis}

Panel A of Table 6 shows the stepwise regression model summary. The model is low in autocorrelation (Durbin-Watson $=2.43$ ) which is significant at $\mathrm{p}<0.05$. Panel B of Table 6 presents the regression coefficients. Only ACSIZE (number of members serving on the AC) and SUB (square root of number of subsidiaries) are left in the model after stepwise regression excludes all non-significant independent variables. The coefficient for ACSIZE is positive and significant $(\mathrm{t}=2.73, \mathrm{p}<0.05)$, indicating that the IAF budget is higher in companies where the AC has more members. Moreover, the coefficient for SUB (control variable) has a positive and significant $(\mathrm{t}=4.11, \mathrm{p}<0.05)$ relationship with the IAF budget. Interestingly, the extent of the IAF budget which would reflect on its work effectiveness is only impacted by the size of AC. Hence, part (a) of the hypothesis is only minimally supported.

This result suggests that a larger sized AC is likely to have more influence over the board of directors in advocating an adequate budget for the IAF. A larger AC may also have more time to work with the IAE and CFO in preparing a stronger case for the IAF budget to be presented to the board. Moreover, a larger AC can give greater attention to monitoring the IAF's funding needs and budget constraints. Such a commitment to reviewing the internal audit's on-going budgetary needs is likely to improve the resources allocated to the IAF. Carcello et al (2005) find that the internal audit budget is higher when an AC reviews the internal audit budget. Raghunandan et al (2001) also find that ACs that review the internal audit budget are associated with a larger budget for internal audit monitoring. Both studies have similar findings to this study. A further possibility is that the IAE can use the AC as a lever if $\mathrm{AC}$ is larger and more powerful within the company when negotiating for extra 
funding within management, particularly during meetings with the management (Abbott et al, 2010).

Table 6. Stepwise regression results for Model 1

\begin{tabular}{|l|c|c|c|c|c|c|}
\hline \multicolumn{1}{|l|}{ PANEL A: Model Summary } \\
\hline R & $\begin{array}{c}\text { R } \\
\text { Square }\end{array}$ & $\begin{array}{c}\text { Adjusted } \\
\text { R Square }\end{array}$ & $\begin{array}{c}\text { Std. Error of } \\
\text { the Estimate }\end{array}$ & $\begin{array}{c}\text { Durbin- } \\
\text { Watson }\end{array}$ & F-ratio & Sig. \\
\hline 0.688 & 0.473 & 0.441 & 0.709 & 2.434 & 7.434 & 0.000 \\
\hline
\end{tabular}

PANEL B: Regression Coefficients

\begin{tabular}{|l|c|c|c|c|c|c|c|}
\hline $\begin{array}{l}\text { Dependent } \\
\text { Variable }\end{array}$ & \multicolumn{2}{|c|}{$\begin{array}{c}\text { Unstandardized } \\
\text { coefficients }\end{array}$} & $\begin{array}{c}\text { Standardized } \\
\text { Coefficients }\end{array}$ & & & \multicolumn{2}{|c|}{$\begin{array}{c}\text { Collinearity } \\
\text { Statistics }\end{array}$} \\
\cline { 2 - 8 } & B & Std. Error & Beta & t-value & Sig. & $\begin{array}{c}\text { Toler } \\
\text { ance }\end{array}$ & VIF \\
\hline Intercept & 0.002 & 0.118 & & 0.018 & 0.986 & & \\
\hline
\end{tabular}

Independent

Variables

\begin{tabular}{|l|l|l|l|l|l|l|l|}
\hline ACSIZE & 0.411 & 0.151 & 0.351 & 2.726 & 0.010 & 0.964 & 1.037 \\
\hline SUB & 0.514 & 0.125 & 0.529 & 4.110 & 0.000 & 0.964 & 1.037 \\
\hline
\end{tabular}

Note: ACCHAIRIND, ACEXP, ACINDUS, ACMEET, ACCHAR, BIG4, LNTA, LEVERAGE, RECRATIO, INVENRATIO, CURATIO, OPCASH, FORSUB, LNAUDFEES and GROWTH are not a significant predictor in this model.

Turning to the test of part (b) of the hypothesis, regression results are shown in Table 7. The model is also low in autocorrelation (Durbin-Watson $=2.45, \mathrm{p}<0.05$ ). The results in Panel B of Table 7 shows that ACEXP (number of AC members with accounting/financial qualifications to total AC members), ACSIZE (number of members serving on the AC) and SUB (square root of number of subsidiaries) are left in the model after stepwise regression excludes all non-significant variables. The coefficients for ACEXP and ACSIZE are positive and significant $(\mathrm{t}=2.10$ and 2.46 respectively, $\mathrm{p}<0.05)$, indicating that labour hours undertaken by the IAF are higher in companies where the AC has more accounting/financial experts and a larger number of members. In addition, the coefficient for SUB (control variable in the model $)$ is positively and significantly $(\mathrm{t}=4.47, \mathrm{p}<0.05)$ related to the IAF labour hours. Number of subsidiaries could be a proxy for the complexity of the IAF's tasks. Hence, part (b) of the hypothesis is also partially supported.

The inference from this result is that an $\mathrm{AC}$ with larger size and comprising of more members with accounting or financial qualifications will be able to bring more pressure on ensuring that labour hours allocated to the IAF are not compromised. In addition, AC members equipped with financial expertise are more likely to have a better understanding of the technicalities and complexities of internal audit tasks related to the company in a particular industry. Results of this study are supported by Goodwin (2003)'s study that find AC members with accounting expertise are more involved in reviewing the work of the IAF and 
ensuring that resources are allocated to the IAF. Moreover, during the review of the IAF budget and plan, larger size and financial experts' AC members have the power to influence the board and management over, not only the amount of labour hours to be allocated to the internal control activities, but also the nature and scope of internal audit programs (Abbott et al, 2010). Furthermore, an AC with financial expertise is more likely to demand the IAF to act and to improve the existing internal control system or increase the amount of work to be done in higher risk areas (Carcello et al, 2005).

Table 7. Stepwise regression results for Model 2

\begin{tabular}{|l|c|c|c|c|c|c|}
\hline \multicolumn{1}{|l|}{ PANEL A: Model Summary } \\
\hline R & $\begin{array}{c}\text { R } \\
\text { Square }\end{array}$ & $\begin{array}{c}\text { Adjusted } \\
\text { R Square }\end{array}$ & $\begin{array}{c}\text { Std. Error of } \\
\text { the Estimate }\end{array}$ & $\begin{array}{c}\text { Durbin- } \\
\text { Watson }\end{array}$ & F-ratio & Sig. \\
\hline 0.728 & 0.531 & 0.487 & 0.675 & 2.447 & 4.415 & 0.044 \\
\hline
\end{tabular}

\section{PANEL B: Regression Coefficients}

\begin{tabular}{|l|c|c|c|c|c|c|c|}
\hline $\begin{array}{l}\text { Dependent } \\
\text { Variable }\end{array}$ & \multicolumn{2}{|c|}{$\begin{array}{c}\text { Unstandardized } \\
\text { coefficients }\end{array}$} & $\begin{array}{l}\text { Standardized } \\
\text { Coefficients }\end{array}$ & & \multicolumn{3}{|c|}{$\begin{array}{c}\text { Collinearity } \\
\text { Statistics }\end{array}$} \\
\cline { 2 - 8 } & B & Std. Error & Beta & t-value & Sig. & $\begin{array}{l}\text { Toler } \\
\text { ance }\end{array}$ & VIF \\
\hline Intercept & 0.001 & 0.113 & & 0.013 & 0.990 & & \\
\hline
\end{tabular}

Independent

Variables

\begin{tabular}{|l|l|l|l|l|l|l|l|}
\hline ACEXP & 0.271 & 0.129 & 0.257 & 2.101 & 0.044 & 0.979 & 1.021 \\
\hline ACSIZE & 0.355 & 0.145 & 0.306 & 2.456 & 0.020 & 0.948 & 1.055 \\
\hline SUB & 0.535 & 0.210 & 0.554 & 4.473 & 0.000 & 0.957 & 1.045 \\
\hline
\end{tabular}

Note: ACCHAIRIND, ACINDUS, ACMEET, ACCHAR, BIG4, LNTA, LEVERAGE, RECRATIO, INVENRATIO, CURATIO, OPCASH, FORSUB, LNAUDFEES and GROWTH are not a significant predictor in this model.

Based on the findings above, it can be posited that $\mathrm{AC}$ size and $\mathrm{AC}$ expertise have an important impact on the effectiveness of an AC's role in supporting the resourcing of the IAF. The evidence indicates that $\mathrm{AC}$ size is more associated with the internal audit budget while both AC expertise and size are associated with the internal audit labour hours.

\subsection{Internal audit function resourcing and its scope of activities}

While some aspects of AC effectiveness as reflected in its governance characteristics have been found to affect the level of budget and hours devoted to the IAF, it can only be assumed that this higher resourcing brings about higher quality of IAF activities. One indicator of IAF quality is the scope of responsibilities it is actively pursuing through its range of activities. Thus, an IAF that devotes its resources to a more complete range of responsibilities as listed by IIA would be providing a more comprehensive range of internal assurance services to the company. 
Table 8 gives cross-tabulation results for higher versus lower IAF budget and hours, respectively. It reveals in Panel A that those companies with higher IAF budget and hours devote a greater proportion of their IAF resources to the activities of control systems, financial statement auditing and risk management. These are all the mainstream assurance functions that would maintain high quality processes and systems needed for internal control, financial reporting and risk management. In contrast, Panel A shows companies with lower IAF budget and hours allocate a greater proportion of these resources to fraud and corporate governance issues. These activities tend to reflect the IAF dealing mainly with crisis situations resulting from inadequate control systems and structures. Moreover, Table 8, Panel $\mathrm{B}$, shows that firms with higher IAF budget and hours undertake a greater diversity of activities. In contrast, firms with lower IAF resourcing have failed to engage in any activity (responsibility) in respect of two or more key categories of responsibility put forward by the IIA. 
Table 8. Comparison of internal audit function resources groupings and internal audit function activities

\begin{tabular}{|c|c|c|c|c|c|c|c|c|c|c|}
\hline \multicolumn{11}{|l|}{ PANEL A } \\
\hline \multirow{2}{*}{$\begin{array}{l}\text { Proportion of } \\
\text { Hours } \\
\text { Allocated to } \\
\text { Types of } \\
\text { Activities }\end{array}$} & \multirow{2}{*}{$\begin{array}{l}\text { Mean } \\
\% \text { of } \\
\text { Total } \\
\text { Hours }\end{array}$} & \multirow[t]{2}{*}{ Mean } & \multicolumn{4}{|c|}{$\begin{array}{l}\text { Size of Internal Audit } \\
\text { Function Budget }\end{array}$} & \multicolumn{4}{|c|}{$\begin{array}{c}\text { Total Hours Devoted } \\
\text { to Internal Audit } \\
\text { Function }\end{array}$} \\
\hline & & & \multicolumn{2}{|c|}{ High } & \multicolumn{2}{|c|}{ Low } & \multicolumn{2}{|c|}{ High } & \multicolumn{2}{|c|}{ Low } \\
\hline \multirow[t]{2}{*}{ Fraud } & \multirow[t]{2}{*}{9} & Above mean & 7 & $33 \%$ & 8 & $53 \%$ & 7 & $37 \%$ & 8 & $47 \%$ \\
\hline & & Below mean & 14 & $67 \%$ & 7 & $47 \%$ & 12 & $63 \%$ & 9 & $53 \%$ \\
\hline \multirow{2}{*}{$\begin{array}{l}\text { Control } \\
\text { Systems }\end{array}$} & \multirow[t]{2}{*}{45} & Above mean & 15 & $71 \%$ & 4 & $27 \%$ & 11 & $58 \%$ & 8 & $47 \%$ \\
\hline & & Below mean & 6 & $29 \%$ & 11 & $73 \%$ & 8 & $42 \%$ & 9 & $53 \%$ \\
\hline \multirow{2}{*}{$\begin{array}{l}\text { Financial } \\
\text { Statement } \\
\text { Auditing }\end{array}$} & \multirow[t]{2}{*}{6} & Above mean & 13 & $62 \%$ & 4 & $27 \%$ & 12 & $63 \%$ & 5 & $29 \%$ \\
\hline & & Below mean & 8 & $38 \%$ & 11 & $73 \%$ & 7 & $37 \%$ & 12 & $71 \%$ \\
\hline \multirow{2}{*}{$\begin{array}{l}\text { Risk } \\
\text { Management }\end{array}$} & \multirow[t]{2}{*}{25} & Above mean & 17 & $81 \%$ & 9 & $60 \%$ & 14 & $74 \%$ & 8 & $47 \%$ \\
\hline & & Below mean & 4 & $19 \%$ & 6 & $40 \%$ & 5 & $26 \%$ & 9 & $53 \%$ \\
\hline \multirow{2}{*}{$\begin{array}{l}\text { Corporate } \\
\text { Governance }\end{array}$} & \multirow[t]{2}{*}{10} & Above mean & 1 & $5 \%$ & 7 & $47 \%$ & 4 & $21 \%$ & 4 & $24 \%$ \\
\hline & & Below mean & 20 & $95 \%$ & 8 & $53 \%$ & 15 & $79 \%$ & 13 & $76 \%$ \\
\hline \multirow[t]{2}{*}{ Others } & \multirow[t]{2}{*}{5} & Above mean & 11 & $52 \%$ & 2 & $13 \%$ & 8 & $42 \%$ & 5 & $29 \%$ \\
\hline & & Below mean & 10 & $48 \%$ & 13 & $87 \%$ & 11 & $58 \%$ & 12 & $71 \%$ \\
\hline Total & $100 \%$ & & & & & & & & & \\
\hline \multicolumn{11}{|l|}{ PANEL B } \\
\hline \multicolumn{3}{|c|}{ Diversity of Activities Undertaken } & \multicolumn{2}{|c|}{ High } & \multicolumn{2}{|c|}{ Low } & \multicolumn{2}{|c|}{ High } & \multicolumn{2}{|c|}{ Low } \\
\hline \multirow[t]{2}{*}{ Diversity } & \multicolumn{2}{|c|}{$\begin{array}{l}\text { Devote Hours to } 5 \text { or } \\
\text { more IAF Activities }\end{array}$} & 16 & $76 \%$ & 8 & $53 \%$ & 12 & $63 \%$ & 11 & $65 \%$ \\
\hline & \multicolumn{2}{|c|}{$\begin{array}{l}\text { Devote Hours to } 4 \text { or } \\
\text { less IAF Activities }\end{array}$} & 5 & 24 & 7 & $47 \%$ & 7 & $37 \%$ & 6 & $35 \%$ \\
\hline
\end{tabular}

\section{Comparative case study}

Findings in Tables 6 and Table 7 concerning both the regression models show that AC size plays a significant role in relation to the effectiveness of AC in resourcing the IAF. A larger AC size in a company brings about a higher budget and hours for the IAF and as suggested in Table 8, this translates into higher quality of IAF services to the company. Using additional information collected from the questionnaire, this section presents a comparative case study analysis between two companies from the financials industry (i.e., banking, finance and insurance) drawn from the sample size of 36 respondents. The companies will be called Company A and Company B hereinafter. 
Company A is a bank and is listed on the ASX top 20 while Company B is an insurance company and is listed on the ASX top 21-100. Company A and Company B are chosen because Company A has the largest AC size with a total of nine members while Company $\mathrm{B}$ has the smallest AC size with a total of three members in the sample. Both companies have the same level of $\mathrm{AC}$ expertise but a different $\mathrm{AC}$ frequency of meetings per year. From the comparison of questionnaire data provided by the IAE of Company A and Company B, it can be seen that there are several distinguish differences between these two companies.

Firstly, substantial differences are found in the distribution of total labour hours allocated to different IAF activities. Company A devotes a consideration portion of internal audit hours to more internal control activities compared to Company B. It can be argued that Company A, having a larger AC size, has a more diverse set of skills and knowledge to oversee and support the IAF's development and execution of its internal control systems. A larger AC will put a stronger emphasis on preventing material control weaknesses and reacting proactively to increase internal controls. The second main difference is Company A's AC has more authority than the $\mathrm{CEO}$ and $\mathrm{CFO}$ in internal audit budget setting, compared to Company $\mathrm{B}$ where the AC has no authority to override the CEO and CFO. It is likely that Company A's larger AC size gives it more authority and voice in internal audit budget setting than Company B's smaller AC size. Larger ACs should command relatively more IAF oversight and be able to demand relatively greater resources and internal audit focus allocated to internal controls. Carcello et al (2005) find a positive association between ACs that reviewed the internal audit's budget and the size of the budget.

To ensure an effective internal control system is implemented within an organization, the AC is responsible to review the internal audit proposals related to plans, programs and coordination with external auditors (Raghunandan et al, 2001). From the comparison between these two companies, it can be seen that Company A's AC often reviews or assesses the plans of the IAF in terms of scheduling of work projects and coordinating with the external auditors, but Company B's AC never does so. This implies that Company A's larger AC has more members with technical expertise collectively have a better understanding of the IAF's work and have the ability to review all the work and plans done by the IAF. Also, Company A's AC receives more reports from its IAF regarding routine internal audit activities and special investigations compared to Company B's AC. It can be argued that more members in the AC will ensure better quality of the IAF by demanding that internal auditors to provide more reports related to internal audit activities. Felo et al (2003) argue that a larger AC increases financial reporting quality as it is more likely to discover and solve potential risks in the financial reporting process. This may be possible if the resources available to the AC are increased to improve the oversight of financial reporting.

The next main difference reported is that Company A's internal audit employees have a longer length of meetings with their $\mathrm{AC}$ (on average 150 minutes per meetings longer) compared to Company B. To improve the effectiveness of the IAF, conducting regular meetings between the AC and the IAF is vital (Scarbrough et al, 1998). Hence, this shows that Company A's larger AC is more efficient in organizing meetings with its internal audit employees and ensures that longer meetings are conducted. More hours spent on conducting a 
meeting will better enable the needs of the organization to be met by ensuring the planned scope of internal auditing issues are discussed and reviewed during the meeting. For IAF independence, it is found that Company A's IAF has a better existing relationship with its AC. Also Company A's internal auditors provide a strong backing for the maintenance of their IAF's independence in contrast to Company B. It is likely that the strong IAF of Company A (i.e., the internal auditors provide a strong backing for the maintenance of their IAF's independence) can enhance the effectiveness of the AC; an effective AC (i.e., larger size) in turn can strengthen the position of the IAF.

Based on the assessment above of the main differences found in the comparative case study analysis between Company A (largest AC size) and Company B (smallest AC size), the findings are compatible with the results from the hypothesis testing.

\section{Conclusions}

The roles of the AC and the IAF have been expanding in the same direction over the past decade. The AC is increasingly expected to play a key role in assisting the board to fulfil its oversight responsibilities in relation to risk management, control, and governance processes, while the IAF's responsibilities now should embrace the evaluation and provision of assurance to management and the $\mathrm{AC}$ on the functioning of these same areas. Strong resourcing of IAF, both in its budget allocation and labour hours, would be a prerequisite for enhancing the scope and quality of its work. The AC's oversight role would clearly be tied to the maintenance or improvement of the scope and quality of the IAF's work which in turn depends on the IAF achieving adequate resourcing. This study uses the AC's governance characteristics to benchmark its effectiveness in relation to the resourcing of the IAF and by extension, the scope and quality of the IAF's activities.

Based on the questionnaire sent to IAEs of top 300 listed companies, the results of this study reveal that AC size is significantly positively related to the financial resources (budget) allocated to the IAF, while both AC financial expertise and AC size are significantly positively related to IAF labour hours. These results infer that a larger size of AC membership, AC would wield more influence over the executive management of the company (and possibly the board) in advocating or gaining authority for a strong budget allocation to the IAF. Moreover, the results show that an $\mathrm{AC}$ with larger size and comprising of more members with accounting or financial qualification will bring more pressure on the company's executive management and board to obtain greater labour hours allocated for the IAF. Results also confirm that IAF's with higher resourcing are able to concentrate those resources in mainstream areas of control systems, risk management and financial statement integrity while also covering the full diversity of activities expected of a high quality IAF. Further, to provide a more in-depth understanding of the AC governance characteristics that are significant in the regression analysis, a comparative case study between two companies is undertaken. The practices identified in this case study give insights to the superior ways a larger size $\mathrm{AC}$ can be effective in fulfilling its oversight role, building its working relationships and obtaining resources for the IAF.

This study has several limitations. First, the data are collected from the use of a questionnaire 
instrument and from hand-extracted secondary data in the annual reports. This data could be subjected to error and bias. In terms of the primary data obtained using the questionnaire, limitations are embodied in the design and administration of any field surveys. Second, the model specification uses variables that do not directly measure the concept of 'role effectiveness' of ACs. Instead various governance characteristics of the AC are measured. The six AC governance characteristics used to measure AC effectiveness (chair independence, financial and industry expertise, size, frequency of meetings and charter) are likely to be built from behavioral and organizational aspects that are not reflected in the proxy measures. Third, the scope of generalization for the results of this study is limited as the sample is confined to the top 300 ASX listed companies and to the 2009- 2010 financial year. Also, the low response rate to the questionnaire means that sample used in this study may not be representative of the population of IAEs.

Nevertheless, the findings of the study have important implications for regulators of corporate governance practices in terms of the composition and functioning of ACs in Australia. More generally, the results of this study should provide IIA Australia or accounting professional bodies with better understanding regarding the effective practice of ACs in overseeing the resourcing needs of the IAF. Furthermore, the results have implications to the users of the annual reports especially the shareholders. Lastly, the findings of this study can help the board of directors to choose ideal AC members to ensure that $\mathrm{AC}$ is at its best in performing its roles as a key corporate governance mechanism in the company.

This study leaves open a number of opportunities for future research. First, future quantitative studies may consider using a more refined measure of independence, expertise, diligence and authority of ACs. Moreover, this study could extend its database to include an investigation of smaller companies listed on the ASX or for privately owned companies, or companies operating in countries with differing regulatory requirements. Second, this study uses quantitative data that serves to highlight statistical average relationships between formally measured variables. A complementary research approach would be to undertake interpretative qualitative methods, particularly case-based interviews and observations that could give deeper understanding of behaviors amongst key organizational players. Future research could consider whether the impacts of behavioral relationships between the AC and the board, and between the $\mathrm{AC}$ and management, are linked to the notion of the AC's effectiveness in fulfilling its roles.

\section{Acknowledgement}

The authors are extremely grateful to the Institute of Internal Auditors (IIA) Australia who provided valuable comments and assisted with the pilot testing of the questionnaire. And also, to the IIA members and the Internal Audit Executives who completed the questionnaire.

\section{References}

Abbott, L. J., \& Parker, S. (2000). The effects of audit committee activity and independence on corporate fraud. Managerial Finance, 26(11), 55-67. https://doi.org/10.1108/03074350010766990 
Abbott, L. J., Parker, S., \& Peters, G. (2003). An empirical investigation of audit fee, non-audit fees and audit committees. Contemporary Accounting Research, 20(2), 215-234. https://doi.org/10.1506/8YP9-P27G-5NW5-DJKK

Abbott, L. J., Parker, S., \& Peters, G. F. (2004). Audit committee characteristics and restatements. Auditing: A Journal of Practice \& Theory, 23(1), 69-87. https://doi.org/10.2308/aud.2004.23.1.69

Abbott, L. J., Parker, S., \& Peters, G. F. (2010). Serving two masters: The association between audit committee internal audit oversight and internal audit activities. Accounting Horizons, 24(1), 1-24. https://doi.org/10.2308/acch.2010.24.1.1

Abbott, L. J., Parker, S., Peters, G. F., \& Raghunandan, K. (2003). The association between audit committee characteristics and audit fees. Auditing: A Journal of Practice \& Theory, 22(2), 17-32. https://doi.org/10.2308/aud.2003.22.2.17

Aldamen, H., Duncan, K., Kelly, S., McNamara, R., \& Nagel, S. (2012). Audit committee characteristics and firm performance during the global financial crisis. Accounting \& Finance, 52(4), 971-1000. https://doi.org/10.1111/j.1467-629X.2011.00447.x

American Bar Association. (1999). Report and recommendations of the blue ribbon committee on improving the effectiveness of corporate audit committees. The Business Lawyer, 54(3), 1067-1095.

Auditing \& Assurance Standards Board, Australian Institute of Company Directors, \& Institute of Internal Auditors Australia. (2008). Audit committees: A guide to good practice. NSW: Ligare Pty Ltd.

Australian Stock Exchange (2003). ASX Corporate Governance Council. Principles of good corporate governance and best practice recommendations. [Online] Available: http://www.asx.com.au/documents/asx-compliance/principles-and-recommendations-march-2 003.pdf (May 19, 2013).

Australian Stock Exchange (2007). ASX Corporate Governance council. Corporate governance principles and recommendations $2^{\text {nd }}$ edition. [Online] Available: http://www.asx.com.au/documents/asx-compliance/final-revised-principles-complete.pdf (May 19, 2013).

Beasley, M. S., Carcello, J. V., Hermanson, D. R., \& Lapides P. D. (2000). Fraudulent financial reporting: Consideration of industry traits and corporate governance mechanisms. Accounting Horizons, 14, 14-21. https://doi.org/10.2308/acch.2000.14.4.441

Carcello, J. V., Hermanson, D. R., Neal, T. L., \& Riley, R. A. (2002). Board characteristics and audit fees. Contemporary Accounting Research, 19(3), 365-384. https://doi.org/10.1506/CHWK-GMQ0-MLKE-K03V

Carcello, J. V., Hermanson, D. R., \& Raghunandan, K. (2005). Factors associated with U.S. public companies' investment in internal auditing. Accounting Horizons, 19(2), 69-84. https://doi.org/10.2308/acch.2005.19.2.69 
Carcello, J. V., \& Neal, T. L. (2000). Audit committee composition and auditor reporting. The Accounting Review, 75(4), 453-467. https://doi.org/10.2308/accr.2000.75.4.453

Christopher, J., Sarens, G., \& Leung, P. (2009). A critical analysis of the independence of the internal audit function: Evidence from Australia. Accounting, Auditing \& Accountability Journal, 22(2), 200-220. https://doi.org/10.1108/09513570910933942

Cooper, B. J. (1993). The audit committee and internal audit. Managerial Auditing Journal, 8(3), 8-10. https://doi.org/10.1108/02686909310036223

Dalton, D. R., Dailey, C. M., Ellstrand, A. E., \& Johnson, J. L. (1998). Meta-analytic reviews of board composition, leadership structure and financial performance. Strategic Management Journal, 19 , 269-290. https://doi.org/10.1002/(SICI)1097-0266(199803)19:3<269::AID-SMJ950>3.0.CO;2-K

Davidson, W. N., Xie, B., \& Xu, W. (2004). Market reaction to voluntary announcements of audit committee appointments: The effect of financial experts. Journal of Accounting and Public Policy, 23, 279-293. https://doi.org/10.1016/j.jaccpubpol.2004.06.001

Deloitte. (2015). The changing role of internal audit. Moving away from traditional internal audits.

[Online]

Available: https://www2.deloitte.com/content/dam/Deloitte/za/Documents/risk/ZA_RA_TheChangingR oleOfInternalAudit_2015.pdf (May 22, 2015).

DeZoort, F. T. (1997). An investigation of audit committees' oversight responsibilities. Abacus, September, 208-227. https://doi.org/10.1111/1467-6281.00012

DeZoort, F. T., Hermanson, D. R., Archambeault, D. S., \& Reed, S. (2002). Audit committee effectiveness: A synthesis of the empirical audit committee literature. Journal of Accounting Literature, 21, 38-75.

DeZoort, F. T., \& Salterio, S. (2001). The effects of corporate governance experience, financial-reporting and audit knowledge on audit committee members' judgements. Auditing: A Journal of Practice and Theory, 20, 31-47. https://doi.org/10.2308/aud.2001.20.2.31

Fama, E. F., \& Jensen, M. C. (1983). Separation of ownership and control. Journal of Law and Economics, 26(2), 301-326. https://doi.org/10.1086/467037

Felo, A. J., Krishnamurthy, S., \& Solieri, S. A. (2003). Audit committee characteristics and the perceived quality of financial reporting: an empirical analysis. Working paper. https://doi.org/10.2139/ssrn.401240

Goddard, A. R., \& Masters, C. (2001). Audit committee, Cadbury Code and audit fees: An empirical analysis of UK companies. Managerial Auditing Journal, 15(7), 358-371. https://doi.org/10.1108/02686900010344638

Goodwin, J. (2003). The relationship between the audit committee and the internal audit function: Evidence from Australia and New Zealand. International Journal of Auditing, 7, 263-278. https://doi.org/10.1046/j.1099-1123.2003.00074.x 
Goodwin, J., \& Kent, P. (2006a). Relation between external audit fees, audit committee characteristics and internal audit. Journal of Accounting and Finance, 46(4), 387-404. https://doi.org/10.1111/j.1467-629X.2006.00174.x

Goodwin, J., \& Kent, P. (2006b). The use of internal audit by Australian companies. Managerial Auditing Journal, 21(1), 81-101. https://doi.org/10.1108/02686900610634775

Goodwin, J., \& Yeo, T. Y. (2001). Two factors affecting internal audit independence and objectivity: Evidence from Singapore. International Journal of Auditing, 5, 107-125. https://doi.org/10.1111/j.1099-1123.2001.00329.x

Gwilliam, D., \& Kilcommins, M. (1998). The impact of audit firm size and audit committee perceptions of auditor independence and financial statement reliability in Ireland. Irish Accounting Review, 5(1), 23-56.

Hair, J. F., Anderson, R. E., Tatham, R. L., \& Black, W. C. (1995). Multivariate data analysis ( $4^{\text {th }}$ ed.). New Jersey: Prentice Hall.

Hoitash, R., \& Hoitash, U. (2008). The role of audit committees in managing relationships with external auditors after SOX. Managerial Auditing Journal, 24(4), 368-397. https://doi.org/10.1108/02686900910948206

IIA Research Foundation (2003). Internal audit reporting relationships: Serving two masters. Altamonte Springs: The Institute of Internal Auditors. [Online] Available: https://na.theiia.org/iiarf/Public\%20Documents/Internal\%20Audit\%20Reporting\%20Relation ships\%20Serving\%20Two\%20Masters.pdf (May 30, 2013).

Institute of Internal Auditors (2002a). The IIA's recommendations to the conference committee on H.R. Altamonte Springs: The Institute of Internal Auditors.

Institute of Internal Auditors (2002b). Recommendations for improving corporate governance. Altamonte Springs: The Institute of Internal Auditors.

Institute of Internal Auditors (2003a). The IIA's position statement on audit committees. Altamonte Springs: The Institute of Internal Auditors.

Institute of Internal Auditors (2003b). The IIA's commentary regarding PCAOB rulemaking docket No.008. Altamonte Springs: The Institute of Internal Auditors.

Institute of Internal Auditors (2004). The role of internal auditing in enterprise-wide risk management. Altamonte Springs: The Institute of Internal Auditors. [Online] Available: http://www.ucop.edu/enterprise-risk-management/_files/role_intaudit.pdf (May 30, 2013).

Jensen, M. C., \& Meckling, W. H. (1976). Theory of the firm: Managerial behaviour, agency costs and ownership structure. Journal of Financial Economics, 3, 305-360. https://doi.org/10.1016/0304-405X(76)90026-X

Kalbers, L. P., \& Fogarty, T. J. (1993). Audit committee effectiveness: An empirical investigation of the contribution of power. Auditing: A Journal of Practice and Theory, 12(1), 24-49. 
Kanel, R., Mausbach, B. T., Kudielka, B. M., \& Orth-Gomer, K. (2008). Relation of morning serum cortisol to prothrombotic activity in women with stable coronary artery disease. $\begin{array}{lllll}\text { Journal Thrombosis and Thrombolysis, } & \text { 25, } & 165- & 172 .\end{array}$ https://doi.org/10.1007/s11239-007-0035-7

Klein, A. (2002). Audit committee, board of director characteristics, and earnings management. Journal of Accounting and Economics, 33, 375-400. https://doi.org/10.1016/S0165-4101(02)00059-9

Lary, A. M., \& Taylor, D.W. (2011). Governance characteristics and role effectiveness of audit committees. Managerial Auditing Journal, 27(4), 336-354. https://doi.org/10.1108/02686901211217969

Lin, J. W., Li, J. F., \& Yang, J. S. (2006). The effect of audit committee performance on earnings quality. Managerial Auditing Journal, 21(9), 921-933. https://doi.org/10.1108/02686900610705019

Munro, L. A., \& Buckby, S. (2008). Audit committee regulation in Australia: How far have we come? Australian Accounting Review, 18(44), 310-323. https://doi.org/10.1111/j.1835-2561.2008.0020.x

Raghunandan, K., Rama, D. V., \& Scarbrough, P. (1998). Accounting and audit knowledge level of Canadian audit committees: Some empirical evidence. Journal of International $\begin{array}{lllll}\text { Accounting, } \quad \text { Auditing } \quad \& \quad \text { Taxation, } & 7(2), & \text { 181-194. }\end{array}$ https://doi.org/10.1016/S1061-9518(98)90013-1

Raghunandan, K., Read, W. J., \& Rama, D. V. (2001). Audit committee composition, "gray directors," and interaction with internal auditing. Accounting Horizons, 15(2), 105-118. https://doi.org/10.2308/acch.2001.15.2.105

Scarbrough, P., Rama, D.V., \& Raghunandan, K. (1998). Audit committee composition and interaction with internal auditing: Canadian evidence. Accounting Horizons, 12(1), 51-62.

Singh, H., \& Newby, R. (2010). Internal audit and audit fees: Further evidence. Managerial Auditing Journal, 25(4), 309-327. https://doi.org/10.1108/02686901011034153

Xie, B., Davidson III, W. N., \& DaDalt, P. J. (2003). Earnings management and corporate governance: The role of the board and the audit committee. Journal of Corporate Finance, 9, 295-316. https://doi.org/10.1016/S0929-1199(02)00006-8

Yatim, P., Kent, P., \& Clarkson, P. (2006). Governance structures, ethnicity, and audit fees of Malaysian listed firms. Managerial Auditing Journal, 21(7), 757-782. https://doi.org/10.1108/02686900610680530

\section{Glossary}

AC: Audit committee.

ASX: Australian stock exchange 


\section{Macrothink}

CEO: Chief executive officer.

CFO: Chief financial officer.

CRO: Chief risk officer.

IAE: Internal audit executive.

IAF: Internal audit function.

IIA: Internal auditors Australia.

\section{Appendix 1: Part of extracts from survey questions}

Question 6: Size of your company based on market capitalization:

$$
\text { ASX Top } 20
$$

ASX 21-100

ASX 101-300

ASX 301-500

ASX Below 500

Question 7: Industry of your company:

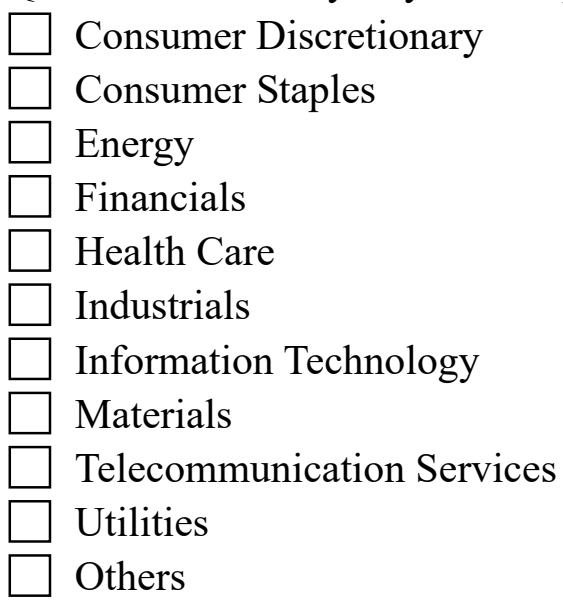

Question 8: How many professional internal audit staff is employed in your company?

Question 9: What is the total annual internal audit budget? (Approximately dollar)
$\square$ \$20 000 and below
$\$ 21000$ to $\$ 50000$
$\$ 51000$ to $\$ 100000$
$\$ 101000$ to $\$ 200000$
$\$ 201000$ to $\$ 500000$
$\$ 501000$ to $\$ 1000000$
$\square$ \$1 001000 and above

Question 10: How many total hours per employee (approximately) were devoted to internal 
audit services during your company's most recent financial year?

Question 11: For the total hours indicated in Question 10, what proportion was allocated to each of the following activities? (Please note that the percentage of hours should add up to $100 \%)$ :

\begin{tabular}{|l|l|}
\hline Activity Description & $\%$ of Hours \\
\hline Deterring and investigating fraud & \\
\hline Maintaining the efficacy of management control systems & \\
\hline Financial statement auditing in collaboration with the external auditors & \\
\hline $\begin{array}{l}\text { Evaluating the effectiveness of risk management, including safe guarding } \\
\text { assets }\end{array}$ & \\
\hline Engaging in board and other corporate governance support work & \\
\hline $\begin{array}{l}\text { Other activities } \\
\text { (please specify: }\end{array}$ & \\
\hline
\end{tabular}

Question 13: Please indicate your level of agreement with the following statements: (Please tick and answer in all three columns)

\begin{tabular}{|c|c|c|c|}
\hline Statement & Audit Committee & Chief Executive Officer & Chief Financial Officer \\
\hline $\begin{array}{l}\text { Your internal } \\
\text { audit } \\
\text { function } \\
\text { regularly } \\
\text { reports to: }\end{array}$ & $\begin{array}{l}\square \text { Strongly Disagree } \\
\square \text { Disagree } \\
\square \text { Neutral } \\
\square \text { Agree } \\
\square \text { Strongly Agree }\end{array}$ & $\begin{array}{l}\square \text { Strongly Disagree } \\
\square \text { Disagree } \\
\square \text { Neutral } \\
\square \text { Agree } \\
\square \text { Strongly Agree }\end{array}$ & $\begin{array}{l}\square \text { Strongly Disagree } \\
\square \text { Disagree } \\
\square \text { Neutral } \\
\square \text { Agree } \\
\square \text { Strongly Agree }\end{array}$ \\
\hline $\begin{array}{l}\text { In setting the } \\
\text { internal } \\
\text { audit's } \\
\text { annual } \\
\text { budget, there } \\
\text { is substantial } \\
\text { involvement } \\
\text { by: }\end{array}$ & $\begin{array}{ll}\square & \text { Strongly Disagree } \\
\square & \text { Disagree } \\
\square & \text { Neutral } \\
\square & \text { Agree } \\
\square & \text { Strongly Agree }\end{array}$ & $\begin{array}{l}\square \text { Strongly Disagree } \\
\square \text { Disagree } \\
\square \text { Neutral } \\
\square \text { Agree } \\
\square \text { Strongly Agree }\end{array}$ & $\begin{array}{l}\square \text { Strongly Disagree } \\
\square \text { Disagree } \\
\square \text { Neutral } \\
\square \text { Agree } \\
\square \text { Strongly Agree }\end{array}$ \\
\hline
\end{tabular}

Question 16: How many times a year does you/ your internal audit function meet with the Audit Committee and how long is the length of the meeting?

Number of meetings a year 
Length of the meetings

(On average, minutes)

Question 19: How often does the Audit Committee review or assess the plans of the internal audit function in terms of its:

\begin{tabular}{|l|c|c|c|c|c|}
\hline & Never & Seldom & Sometimes & Often & $\begin{array}{c}\text { Almost } \\
\text { Always }\end{array}$ \\
\hline $\begin{array}{l}\text { Scheduling of work } \\
\text { projects }\end{array}$ & $\square$ & $\square$ & $\square$ & $\square$ & $\square$ \\
\hline $\begin{array}{l}\text { Co-ordinating with the } \\
\text { external auditor }\end{array}$ & $\square$ & $\square$ & $\square$ & $\square$ & $\square$ \\
\hline
\end{tabular}

Question 20: How often per year does the Audit Committee receive reports from your internal audit function related to:

\begin{tabular}{|l|c|c|c|c|}
\hline & None per year & 1- 2 per year & 3- 5 per year & $\begin{array}{c}\text { 6 or more } \\
\text { per year }\end{array}$ \\
\hline $\begin{array}{l}\text { Routine internal audit } \\
\text { activities }\end{array}$ & $\square$ & $\square$ & $\square$ & $\square$ \\
\hline Special investigations & $\square$ & $\square$ & $\square$ & $\square$ \\
\hline
\end{tabular}

Question 21: Please indicate your level of agreement with the following statements:

\begin{tabular}{|l|c|c|c|c|c|}
\hline Statement & $\begin{array}{c}\text { Strongly } \\
\text { Disagree }\end{array}$ & Disagree & Neutral & Agree & $\begin{array}{c}\text { Strongly } \\
\text { Agree }\end{array}$ \\
\hline $\begin{array}{l}\text { The existing relationship between } \\
\text { the Audit Committee (or its chair) } \\
\text { and the internal auditor provides a } \\
\text { strong backing for the maintenance } \\
\text { of your internal audit function's } \\
\text { independence }\end{array}$ & $\square$ & $\square$ & $\square$ & $\square$ & $\square$ \\
\hline
\end{tabular}

\section{Copyright Disclaimer}

Copyright for this article is retained by the author(s), with first publication rights granted to the journal.

This is an open-access article distributed under the terms and conditions of the Creative Commons Attribution license (http://creativecommons.org/licenses/by/3.0/). 